\title{
EFEKTIVITAS PENAGIHAN PAJAK DENGAN SURAT TEGURAN DAN SURAT PAKSA TERHADAP PENERIMAAN PAJAK PADA KANTOR PELAYANAN PAJAK PRATAMA SLEMAN
}

\author{
Fika Wahyuningtyas
}

Alia Ariesanti

\begin{abstract}
Tax collection by using a letter of reprimand and forced letter is an effort to increase the effectiveness of tax revenue that purpose as the country's development. This research method aims to determine the level of effectiveness of the tax collection and forced letter warning letter. The research method uses descriptive method of analysis, methods based on existing data, and then draw conclusions. This study uses secondary limit the period 2011-2012. Analysis using ratio analysis to calculate the effectiveness of tax collection by using related variables that include the amount of the tax billing plan and the amount of tax revenue. The results showed that the effectiveness of tax collection with a letter of reprimand and a letter run ineffectively enforced, so expect authorize agencies in collecting tax debts can be optimized, see realize taxes are still very small.
\end{abstract}

Keywords: Effectiveness, billing taxes, letter of reprimand, and forced Letter

\section{PENDAHULUAN}

Penerimaan dari sektor perpajakan merupakan penerimaan terpenting dalam anggaran pendapatan dan belanja. Pada APBN tahun 2012 dari target penerimaan negara sebesar Rp1.352,8 triliun, komposisi penerimaan pajak Rp1.016,2 triliun. Hal ini berarti penerimaan perpajakan berkontribusi sekitar $75 \%$ penerimaan negara. Pada tahun 2013 penerimaan perpajakan direncanakan mencapai Rp1.178,9 triliun, naik sebesar 16\% dibandingkan dengan target perubahan tahun 2012 sebesar Rp1.016,2 triliun. Pada tahun 2012, realisasi penerimaan perpajakan baru mencapai 94,38\% dari target Rp885,02 triliun atau sekitar Rp835,25 triliun (www.detikfinance.com).

Kondisi penerimaan 2012 yang baru mencapai 94,38\% dan target penerimaan yang cukup tinggi di 2012 menjadi salah satu faktor dilaksanakannya sensus pajak nasional di 2011 dan berakhir di 2012. Berdasarkan data yang ada di Direktorat 
Jendral Pajak menunjukkan bahwa dari 238 juta penduduk Indonesia, sekitar 44 juta orang dianggap layak membayar pajak, tetapi dari jumlah itu hanya 8,5 juta orang yang memenuhi kewajiban perpajakan. Sektor wajib pajak badan, yang tercatat di Direktorat Jendral Pajak terdapat 22,6 juta badan usaha baik yang berdomisili tetap maupun tidak, namun hanya 466 ribu badan usaha yang membayar pajak. Dari data tersebut bisa dilihat bahwa tingkat kepatuhan wajib pajak (tax compliance) dalam memenuhi kewajiban perpajakan masih sangat rendah. (www.hitungpajak.wordpress.com).

Beberapa upaya telah dilakukan oleh pemerintah dalam rangka meningkatkan penerimaan pajak dengan berbagai cara, salah satunya adalah dengan reformasi pajak (tax reform). Bentuk nyata reformasi pajak terjadi pada tahun 1983, dimana sistem pemungutan pajak dirubah dari official assessment system menjadi self assessment system. Selain itu, pemerintah juga memposisikan diri sebagai law enforcement agent yaitu tindak penegak hukum yang meliputi pemeriksaan, penyidikan dan pengalihan. Hal ini dilakukan agar penerimaan negara dari pos pajak menjadi lebih optimal, namun optimalisasi pajak tersebut terjadi banyak kendala antara lain tingginya angka tunggakan pajak baik yang murni melakukan tax avoidance maupun ketidakmampuan membayar pajak. (www.hitungpajak.wordpress.com).

Menurut Undang-Undang Nomor 19 Tahun 2000, terdapat salah satu kewenangan Direktorat Jenderal Pajak untuk mengatasi kendala tersebut yaitu tindakan penagihan yang mempunyai kekuatan hukum yang memaksa. Tindakan penagihan meliputi pemberitahuan, penagihan seketika dan sekaligus, pemberitahuan surat paksa, melaksanakan penyitaan, melaksanakan penyanderaan serta menjual barang yang telah disita.

Tindakan penagihan merupakan wujud upaya untuk mencairkan tunggakan pajak, namun dalam pelaksanaan penagihan haruslah memperhatikan prinsip keseimbangan antara biaya penagihan dengan penerimaan yang didapatkan karena pelaksanaan penagihan dalam rangka pencairan tunggakan pajak mengeluarkan 
biaya yang tidak sedikit. Beberapa upaya penagihan pajak yang telah ditetapkan oleh pemerintah, diharapkan ada satu tahapan yang tidak perlu mengeluarkan lebih banyak biaya dan lebih banyak waktu untuk memprosesnya. Untuk itu penulis tertarik untuk mengangkat kedalam penelitian mengenai efektivitas penagihan pajak dengan surat teguran dan surat paksa terhadap penerimaan pajak Kantor Pelayanan Pajak Pratama Sleman.

\section{KAJIAN TEORITIS}

\section{Pengertian Pajak}

Pajak merupakan salah satu perwujudan dan kewajiban kenegaraan yang merupakan sarana peran serta masyarakat dalam pembiayaan negara dan pembangunan nasional. Pajak dipungut oleh negara dan digunakan untuk menjalankan roda pemerintahan demi menjamin kelangsungan hidup serta meningkatkan mutu kehidupan bangsa Indonesia yang tercantum dalam pembukaan UUD 1945 yang bertujuan memajukan kesejahteraan umum, mencerdaskan kehidupan bangsa dan turut serta melaksanakan ketertiban dunia.

Undang-Undang Nomor 28 Tahun 2007 tentang Perubahan Ketiga atas Undang-Undang Nomor 6 Tahun 1983 tentang ketentuan umum dan tata cara Perpajakan (KUP) bahwa pajak adalah kontribusi wajib pajak kepada negara yang terutang oleh pribadi atau badan yang bersifat memaksa berdasarkan undangundang dengan tidak mendapatkan imbalan secara langsung dan digunakan untuk keperluan negara bagi sebesar-besarnya kemakmuran rakyat.

\section{Sistem Pemungutan Pajak}

Pajak dipungut untuk dapat membiayai penyelenggaraan pemerintah. Terdapat tiga sistem pemungutan pajak menurut Mardiasmo (2009: 7), yaitu:

1. Official assesment system, sistem ini merupakan sistem pemungutan pajak yang memberi wewenang kepada pemerintah untuk menentukan besarnya pajak yang terutang. 
2. Self assesment system, sistem ini merupakan pemungutan pajak yang memberikan wewenang, kepercayaan, tanggung jawab kepada Wajib Pajak untuk menghitung, memperhitungkan, membayar, dan melaporkan sendiri besarnya pajak yang harus dibayar.

3. Withholding system, sistem ini merupakan sistem pemungutan pajak yang memberi wewenang kepada pihak ketiga untuk memotong atau memungut besarnya pajak terutang oleh Wajib Pajak.

\section{Penagihan Pajak}

Penagihan Pajak merupakan serangkaian tindakan agar Penanggung Pajak melunasi utang pajak dan biaya penagihan pajak dengan menegur atau memperingatkan, melaksanakan penagihan seketika dan sekaligus, memberitahukan Surat Paksa, mengusulkan pencegahan, melaksanakan penyitaan, melaksanakan penyanderaan, menjual barang yang telah disita (Pasal 1angka 9 UU No. 19/2000 tentang penagihan pajak dengan surat paksa).

Tindakan penagihan pajak didahului dengan Surat Teguran yang telah diterbitkan 7 (tujuh) hari sejak tanggal jatuh tempo dari surat ketetapan pajak yaitu STP, SKPKB, SKPBT, SK Pembetulan dan Putusan banding setelah proses berjalan Surat Teguran berjalan maka dilanjutkan dengan menerbitkan Surat Paksa hingga melakukan pelelangan, maka dapat digambarkan proses penagihan dalam tabel 1:

\section{Tabel 1}

\section{Proses Penagihan Pajak}

\begin{tabular}{|c|l|l|c|}
\hline Urutan & $\begin{array}{l}\text { Tahapan kegiatan } \\
\text { penagihan }\end{array}$ & Waktu pelaksanan kegiatan & Dasar hukum \\
\hline 1 & $\begin{array}{l}\text { Penerbitan surat } \\
\text { teguran atau surat } \\
\text { peringatan atau } \\
\text { surat lain yang } \\
\text { sejenis }\end{array}$ & $\begin{array}{l}7 \text { (tujuh) hari sejak saat jatuh } \\
\text { tempo utang pajak penganggung } \\
\text { pajak tidak melunasi utang } \\
\text { pajaknya }\end{array}$ & \\
\hline 2 & $\begin{array}{l}\text { Penerbitan Surat } \\
\text { Paksa }\end{array}$ & $\begin{array}{l}\text { Sudah lewat 21 (dua puluh satu) } \\
\text { hari sejak diterbitkannya Surat } \\
\text { teguran / surat peringatan dan }\end{array}$ & $\begin{array}{l}\text { (pasal 7 UU Nomor } \\
\text { s.d 23 peraturan mentri }\end{array}$ \\
\hline
\end{tabular}




\begin{tabular}{|c|l|l|lr|}
\hline & & $\begin{array}{l}\text { penanggung pajak tidak } \\
\text { melunasi utang pajak }\end{array}$ & $\begin{array}{l}\text { keuangan nomor } \\
\text { 24/PMK.03/2008 }\end{array}$ \\
\hline 3 & $\begin{array}{l}\text { Penerbitan surat } \\
\text { perintah melakukan } \\
\text { penyitaan }\end{array}$ & $\begin{array}{l}\text { Setelah lewat 2x24 jam surat } \\
\text { paksa diberitahukan kepada } \\
\text { penanggung pajak dan utang } \\
\text { pajak belum dilunasi }\end{array}$ & $\begin{array}{l}\text { Pasal 12 UU Nomor } \\
19 / 2000\end{array}$ \\
\hline 4 & $\begin{array}{l}\text { Pengumuman } \\
\text { lelang }\end{array}$ & $\begin{array}{l}\text { Setelah lewat waktu 14 hari } \\
\text { sejak tanggal pelaksanaan } \\
\text { penyitaan dan penanggung pajak } \\
\text { tidak melunasi utang pajak }\end{array}$ & $\begin{array}{l}\text { Pasal 26 peraturan } \\
\text { mentri } \\
\text { nomor } \\
\text { 24/PMK.03.2008 }\end{array}$ \\
\hline 5 & $\begin{array}{l}\text { Penjualan atau } \\
\text { pelelangan barang } \\
\text { sitaan }\end{array}$ & $\begin{array}{l}\text { Setelah lewat waktu 14 (empat } \\
\text { belas) hari sejak pengumuman } \\
\text { leleng dan penanggung pajak } \\
\text { tidak melunasi utang pajaknya }\end{array}$ & $\begin{array}{l}\text { Pasal 26 UU Nomor } \\
\text { 19/2000 dam pasal 28 } \\
\text { peraturan mentri } \\
\text { keuangan nomor } \\
\text { 24/PMK.03.2008 }\end{array}$ \\
\hline
\end{tabular}

Sumber: Suhartono dan Ilyas (2011: 80)

\section{Penagihan Pajak dengan Surat Teguran}

Penerbitan surat teguran, surat peringatan, atau surat lain yang sejenis merupakan awal tindakan penagihan pajak sehingga hal tersebut menjadi pedoman tindakan penagihan pajak berikutnya yaitu penyampain surat paksa dan sebagainya. Sesuai pasal 8 ayat (2) UU PPSP, surat teguran / surat peringatan atau surat lain yang sejenis diterbitkan apabila penanggung pajak tidak melunasi utang pajak yang sampai dengan tanggal jatuh tempo pembayaran. Pasal 1 angka 10 UU PPSP menyebutkan bahwa surat teguran, surat peringatan atau surat lain yang sejenis adalah surat yang diterbitkan oleh pejabat untuk menegur atau memperingati kepada wajib pajak untuk melunasi utang pajaknya. Penentuan tanggal jatuh tempo sendiri diungkapkan. Dalam KUP oleh Suhartono dan Ilyas (2012: 140).

\section{Penagihan Pajak dengan Surat Paksa}

Menurut Fidel (2012;47) UU Penagihan Pajak dengan Surat Paksa (PPSP) yaitu:

a) Falsafah UU PPSP No. 19/2000

1. Menampung perkembangan sistem hukum nasional perlunya dipertegas perolehan hak karena waris dan hibah wasiat yang merupakan objek pajak. 
2. Mendorong peningkatan kesadaran dan kepatuhan masyarakat dalam memenuhi kewajiban perpajakannya.

3. Adanya kepastian hukum dan menegakkan keadilan.

b) Tujuan perubahan UU PPSP No. 19/2000

1. Banyaknya tunggakan pajak dari waktu ke waktu menunjukkan jumlah yang semakin besar, untuk itu perlu dilaksanakannya tindakan penagihan pajak yang mempunyai kekuatan hukum yang memaksa.

2. Keputusan Wajib Pajak dalam membayar pajak merupakan posisi strategis dalam peningkatan penerimaan pajak.

3. Penagihan pajak yang dilaksanakan secara konsisten dan berkesinambungan untuk meningkatkan kepatuhan yang menimbulkan aspek psikologis bagi Wajib Pajak.

4. Memberikan perlindungan hukum, baik kepada penanggung pajak maupun kepada pihak ketiga berupa hak untuk mengajukan gugatan.

\section{RERANGKA PIKIR}

Pemerintah telah melakukan reformasi perpajakan untuk meningkatkan penerimaan negara dari sektor pajak. Reformasi perpajakan tahun 1983, sistem pemungutan pajak telah mengalami perubahan yang cukup signifikan yaitu official assement system dan self assesment system. Self assesment system, wajib pajak diberikan kepercayan penuh untuk menghitung, memperhitungkan, menyetor dan melaporkan sendiri pajaknya. Namun, dalam kenyataannya masih dijumpai adanya tunggakan pajak sebagai akibat tidak dilunasinya utang pajak sebagaimana mestinya, sehingga perlu dilaksanakan tindakan penagihan yang mempunyai kekuatan hukum yang memaksa.

Salah satu tindakan penagihan pajak adalah dengan pemberitahuan surat teguran dan surat paksa. Dasar dari penagihan pajak adalah adanya tunggakan pajak dalam Surat Tagihan Pajak, Surat Ketetapan Pajak Kurang Bayar, Surat Ketetapan Pajak Kurang Bayar Tambahan, Surat Keputusan Pembetulan, Surat Keputusan 
Keberatan, dan Putusan Banding. Apabila realisasi pencarian tunggakan pajak tersebut dapat direalisasikan dengan jumlah nominal hampir sama dengan surat paksa tersebut telah efektif.

Efektivitasnya penagihan pajak dengan surat paksa maka dapat meningkatkan penerimaan pajak, diharapkan memberikan kontribusi terhadap pembangunan nasional. Oleh karena itu efektivitas penagihan pajak dengan surat teguran dan surat paksa sangat diperlukan untuk meningkatkan penerimaan negara dari sektor pajak.

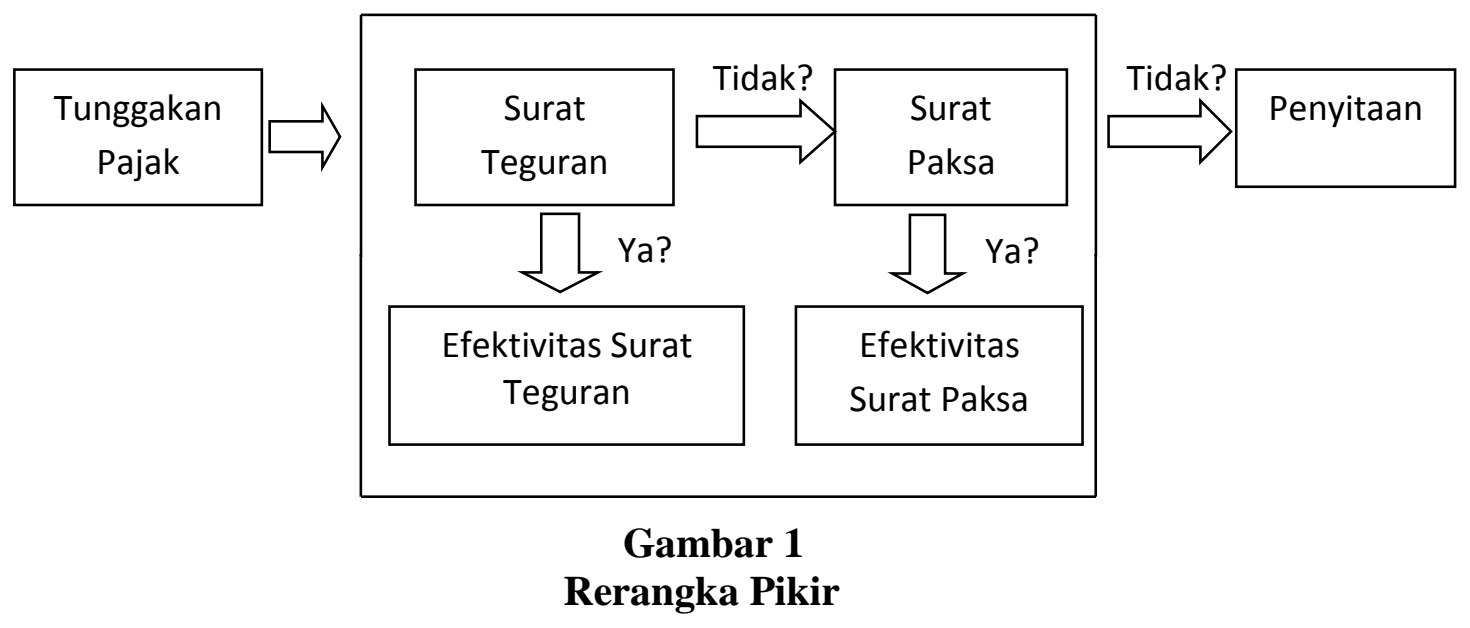

\section{Hasil Penelitian Terdahulu}

Penelitian tentang surat paksa telah banyak dilakukan oleh peneliti terdahulu. Beberapa peneliti terdahulu yang berkaitan dengan surat paksa diantaranya dikutip dari beberapa sumber penelitian, antara lain:

1. Hasil penelitian Purnawan (2004) menyimpulkan bahwa wajib pajak patuh memenuhi kewajibannya bukan karena takut kena sanksi melainkan, wujud dari tanggung jawab dan kesadaran akan arti pentingnya pajak bagi pembangunan, di sisi lain pemerintah harus meningkatkan pelayanan kepada publik sebagai wujud tanggung jawab kepada masyarakat.

2. Mayang (2010) menunjukkan hasil yang signifikan, setelah wajib pajak mendapatkan penagihan pajak dengan surat paksa maka wajib pajak akan melakukan kewajiban perpajakannya. 
3. Nana (2012) menjelaskan penagihan pajak dengan surat paksa di KPP Makasar Selatan tergolong tidak efektif baik ditinjau dari segi jumlah lembar maupun nilai nominal yang tertera dalam surat teguran dan surat paksa. Penyebab pencarian surat paksa tidak mencapai $100 \%$ antara lain penanggung pajak tidak mengakui adanya utang pajak, penanggung pajak tidak mampu melunasi utang pajaknya, penanggung pajak mengajukan surat permohonan angsuran pembayaran karena kondisi keuangan tidak memungkinkan jika dibayarkan sekaligus, penanggung pajak mengajukan keberatan atas jumlah tunggakan pajaknya, dan penanggung pajak lalai.

\section{Metoda Penelitian}

\section{Objek Penelitian}

Objek penelitian adalah Penagihan Pajak dengan Surat Teguran dan Surat Paksa di Kantor Pelayanan Pajak Pratama Sleman, diharapkan dengan dikeluarkannya Surat Teguran dan Surat Paksa dapat meningkatkan penerimaan pajak yang belum tertagih pada Kantor Pelayanan Pajak Pratama Sleman, dengan ini kita dapat mengetahui penerimaan pajak di KPP Pratama Sleman telah mencapai tingkat efektivitas yang diharapkan.

\section{Objek Penelitian}

Penelitian ini dilaksanakan di Kantor Pelayanan Pajak Pratama Sleman, Gedung Direktorat Jendral Pajak (DJP) DIY Jl. Ring Road Utara No. 10 Maguwoharjo, Depok, Sleman, Yogyakarta. Penelitian ini dilakukan untuk mengetahui penagihan, penerimaan pajak dan efektivitas pajak dengan surat teguran dan surat paksa. Data yang digunakan penelitian ini adalah data tahun 2011 sampai 2012. 


\section{Sumber Data dan Metoda Pengumpulan Data}

1. Sumber data yang digunakan dalam penelitian adalah berupa data sekunder, yaitu data yang diperoleh merupakan data olahan dari instansi yang bersangkutan dan data-data yang digunakan untuk mendukung hasil penelitian.

2. Sumber referensi yaitu dari literatur, artikel dan berbagi sumber lain yang berhubungan dengan masalah penelitian.

3. Jenis data, dalam penelitian ini tidak terlepas dari adanya jenis data yang akan dikumpulkan sebagai bahan penelitian. Data rasio yang dikumpulkan berupa laporan kinerja seksi penagihan, laporan penerimaan pajak, serta data-data lain yang terkait dengan penelitian.

4. Studi lapangan melalui dokumentasi, yaitu pengumpulan data-data dengan melakukan review terhadap dokumen yang berkaitan dengan masalah penelitian yang terkait seperti di Kantor Pelayanan Pajak Pratama Sleman. Data yang diperlukan dalam penelitian ini adalah:

a. Data target dan realisasi penerimaan Pajak Kabupaten Sleman per tahun anggaran 2011 sampai tahun 2012

b. Data Surat Teguran dan Surat Paksa yang telah diterbitkan dan dicairkan dalam bentuk rupiah di KPP Pratama Sleman

c. Data Wajib Pajak Pribadi dan Wajib Pajak Badan KPP Pratama Sleman yang terdaftar per tahun 2011 dan 2012

d. Profil Kantor Pelayanan Pajak Pratama Sleman

e. Data jumlah pajak yang tidak tertagih di KPP Pratama Sleman per tahun 2011 dan 2012

f. Data Pencairan Tunggakan Pajak dan Penerimaan Pajak per tahun 2011 dan 2012

\section{Teknik Analisis Data}

Setelah data terkumpul, kemudian dilakukan analisis data. Analisis data yang digunakan peneliti adalah analisis deskriptif yaitu analisis yang menekankan pada 
pembahasan data-data dan objek penelitian dengan menyajikan data-data secara sistematika dan dapat menyimpulkan hasil penelitian dengan menggunakan teknik analisis deskriptif rasio. Analisis rasio yang digunakan adalah rasio efektivitas. Ukuran efektivitas penerbitan dengan Surat Teguran dan efektivitas dengan Surat Paksa. Rumus menghitung tingkat efektivitas penerbitan surat teguran sebagai berikut:

\begin{tabular}{|c|c|} 
Efektifitas Surat Teguran $=$ & $\begin{array}{c}\text { Jumlah rupiah yang dibayar melalui } \\
\text { surat teguran }\end{array}$ \\
& $\begin{array}{c}\text { Jumlah rupiah yang diterbitkan } \\
\text { melalui surat teguran }\end{array}$ \\
\hline
\end{tabular}

Hasil perbandingan tingkat efektivitas dapat digolongkan ke dalam beberapa kategori dikutip oleh Fatchanie (2007: 23) yaitu:

1. Hasil perbandingan tingkat pencapaian di atas $100 \%$ berarti sangat efektif.

2. Hasil perbandingan tingkat pencapaian $100 \%$ berarti efektif.

3. Hasil perbandingan tingkat pencapaian di bawah $100 \%$ berarti tidak efektif.

Semakin besar persentase efektivitas yang diperoleh maka menunjukkan bahwa realisasi penerimaan pajak sesuai dengan target penerimaan pajak dengan menggunakan Surat teguran dan sebaliknya semakin kecil nilai yang diperoleh berarti realisasi penerimaan pajak tidak sesuai dengan target penerimaan yang diharapkan. Sehingga bila target penerimaan pajak dengan surat teguran belum mencapai target realisasinya maka digunakan rasio efektivitas dengan menggunakan surat paksa. Menghitung tingkat efektivitas penerbitan surat paksa.

\begin{tabular}{|cc|}
\hline Efektifitas Surat Paksa $=$ & $\begin{array}{c}\text { Jumlah rupiah yang dibayar melalui } \\
\text { surat paksa }\end{array}$ \\
\cline { 2 - 2 } & $\begin{array}{c}\text { Jumlah rupiah yang diterbitkan } \\
\text { melalui surat paksa }\end{array}$ \\
\hline
\end{tabular}

Semakin besar persentase efektivitas yang diperoleh maka menunjukkan bahwa realisasi penerimaan pajak dengan Surat Paksa sesuai dengan target 
penerimaan pajak, sebaliknya semakin kecil nilai yang diperoleh berarti realisasi penerimaan pajak tidak sesuai dengan target penerimaan yang diharapkan.

\section{HASIL ANALISIS DATA}

\section{Deskripsi Penelitian}

Efektivitas penerimaan pajak dalam penelitian ini berdasarkan data sekunder yang diperoleh dari Seksi Penagihan Kantor Pelayanan Pajak Sleman. Data yang dibutuhkan meliputi target dan realisasi penerimaan pajak, target dan realisasi pencairan pajak, target dan realisasi penagihan pajak dengan Surat teguran dan Surat Paksa tahun 2011 dan 2012. Dengan demikian dapat memberi informasi sebesar apa Efektivitas Penagihan dengan Surat Teguran dan Surat Paksa terhadap Penerimaan di Kantor Pelayanan Pajak Pratama Sleman.

\section{Penagihan Pajak dengan Surat Teguran dan Surat Paksa}

Analisis penagihan tunggakan pajak dengan surat teguran dan surat paksa pada KPP Sleman dinyatakan secara deskriptif dengan membandingkan penagihan tunggakan pajak pada tahun yang bersangkutan dengan penagihan tunggakan pajak tahun sebelumnya. Penagihan dengan Surat Teguran merupakan tindakan penagihan yang dilaksanakan oleh Jurusita Pajak dengan menyampaikan Surat Teguran kepada Wajib Pajak untuk melunasi utang pajak dan biaya penagihan, dengan rincian sebagai berikut:

Tabel 2

Penagihan Pajak dengan Surat Teguran

KPP Pratama Sleman Tahun 2011 dan 2012

\begin{tabular}{|c|c|c|}
\hline Tahun 2011 & Tahun 2012 & $\begin{array}{c}\text { Kenaikan/ } \\
\text { Penurunan }(\mathbf{R p})\end{array}$ \\
\hline Rp27.718.461.904 & Rp25.451.681.229 & $(\operatorname{Rp} 2.266 .780 .675)$ \\
\hline
\end{tabular}

Sumber: Seksi Penagihan KPP Pratama Sleman, data diolah (2013)

Berdasarkan tabel 2 penagihan pajak dengan surat teguran pada umumnya mengalami jumlah penurunan nilai nominal yang tertera dalam surat teguran. 
Penagihan surat teguran pada tahun 2011 dengan nominal sebanyak Rp27.718.461.904, sedangkan pada tahun 2012 dengan nilai nominal sebanyak Rp25.451.681.229, berarti ada selisih penurunan jumlah nominal sebesar Rp2.266.780.657, sehingga lebih banyak yang melakukan penagihan surat teguran ditahun 2011 dibandingkan dengan tahun 2012.

Tabel 3

Penagihan Pajak dengan Surat Paksa

KPP Pratama Sleman Tahun 2011 dan 2012

\begin{tabular}{|c|c|c|}
\hline Tahun 2011 & Tahun 2012 & Kenaikan/Penurunan \\
\hline Rp8.273.709.039 & Rp19.286.401.363 & Rp11.012.692.324 \\
\hline
\end{tabular}

Sumber: Seksi Penagihan KPP Pratama Sleman, data diolah (2013)

Berdasarkan tabel 3 penagihan pajak dengan surat paksa mengalami kenaikan, di tahun 2011 yang hanya menerbitkan surat paksa dengan nominal Rp8.273.709.039 sedangkan penerbitan surat paksa di tahun 2012 mengalami peningkatan yaitu dengan nilai nominal Rp19.286.401.136, dengan demikian bahwa penerbitan surat paksa mengalami peningkatan jumlah nominal dari tahun 2011 sampai tahun 2012. Selisih nominal sebesar Rp11.012.692.324.

Penagihan pajak dengan surat teguran tahun 2011 ke tahun 2012 mengalami penurunan penerbitan surat teguran yang diterbitkan tahun 2011 sebesar Rp27.718.461.904, sedangkan pada tahun 2012 sebesar Rp25.451.681.229. Sehingga mempengaruhi tingkat penerimaan dengan surat teguran.

Tabel 4

Penerimaan Pajak dengan Surat Teguran

KPP Pratama Sleman Tahun 2011 dan 2012

\begin{tabular}{|c|c|c|}
\hline Tahun 2011 & Tahun 2012 & Kenaikan/Penurunan \\
\hline Rp2.703.816.474 & Rp2.028.806.521 & (Rp675.009.953) \\
\hline
\end{tabular}

Sumber: Seksi Penagihan KPP Pratama Sleman, data diolah (2013)

Berdasarkan tabel 4 penerimaan tunggakan pajak dengan surat teguran mengalami penurunan sebesar Rp675.009.953, yaitu penerimaan pajak di tahun 
2011 sebesar Rp2.703.816.474 sedangkan di tahun 2012 menurun sebesar Rp2.028.806.521.

Sedangkan dari penagihan pajak dengan surat paksa tahun 2011 ke tahun 2012 mengalami kenaikan jumlah nominal, penerbitan surat paksa yang diterbitkan tahun 2011 sebesar Rp8.273.709.039, sedangkan pada tahun 2012 sebesar Rp19.286.401.363, peningkatan ini mempengaruhi penerimaan dengan surat paksa

Tabel 5

Penerimaan Pajak dengan Surat Paksa

KPP Pratama Sleman Tahun 2011 dan 2012

\begin{tabular}{|c|c|c|}
\hline Tahun 2011 & Tahun 2012 & Kenaikan/Penurunan \\
\hline Rp3.251.099.607 & Rp11.752.880.392 & Rp8.501.780.785 \\
\hline
\end{tabular}

Sumber: Seksi Penagihan KPP Pratama Sleman, data diolah (2013)

Berdasar tabel 5 penerimaan tunggakan pajak dengan surat paksa umumnya mengalami peningkatan. Penerimaan tunggakan pajak dengan surat paksa pada tahun 2011 sebesar Rp3.251.099.607 dan pada tahun 2012 sebesar Rp11.752.880.392. Jika dilihat dari nilai nominalnya ada penerimaan tunggakan pajak dari tahun 2011-2012 yaitu sebesar Rp8.501.780.785.

\section{Efektivitas Penerimaan Pajak dengan Surat Teguran}

Efektivitas merupakan hubungan antara keluaran dengan tujuan yang akan dicapai. Tingkat efektivitas penerimaan pajak dengan surat teguran pajak di KPP Sleman, dapat dilihat dengan rumus:

Efektifitas Surat Teguran $=\frac{\begin{array}{c}\text { Jumlah rupiah yang harus dibayar } \\ \text { melalui surat teguran }\end{array}}{\begin{array}{c}\text { Jumlah rupiah yang diterbitkan } \\ \text { melalui surat teguran }\end{array}}$ X 100\%


Tabel 6

Tingkat Efektivitas Penagihan Pajak terhadap Penerimaan Pajak dengan Surat Teguran

\begin{tabular}{|c|c|c|c|}
\hline Tahun & ST Terbit (Rp) & ST Bayar (Rp) & Tingkat Efektivitas(\%) \\
\hline 2011 & 27.718 .461 .904 & 2.703 .816 .474 & 10,2516 \\
\hline 2012 & 25.451 .681 .229 & 2.028 .806 .521 & 12,5451 \\
\hline
\end{tabular}

Sumber: Seksi Penagihan KPP Pratama Sleman, data diolah (2013)

Tabel 6 menunjukkan bahwa penerbitan surat teguran pada tahun 2011 di KPP Sleman tercatat Rp27.718.461.904 dan yang dibayarkan sebesar Rp2.703.816.474 atau sekitar 10,25\%. Berdasarkan pengukuran efektivitas penerbitan surat teguran tahun 2011 tergolong tidak efektif karena tingkat efektivitas tidak mencapai $100 \%$.

Tahun 2012 mengalami penurunan penerbitan surat teguran sebesar Rp25.451.681.229 dan yang dibayarkan Rp2.028.806.521 atau sekitar 12,54\%. Berdasarkan pengukuran efektivitas penerbitan surat teguran tahun 2012 tergolong tidak efektif karena tingkat efektivitas tidak mencapai $100 \%$.

Ada beberapa hal yang menyebabkan tidak seluruh Surat Teguran tidak dilunasi oleh penanggung pajak yaitu:

1. Surat Teguran dikirim melalui kantor Pos.

2. Alamat Penanggung Pajak yang telah pindah.

3. Penanggung pajak lalai melunasi utang pajak.

4. Penanggung pajak tidak mampu dalam melunasi utang pajak.

5. Penanggung pajak tidak mengakui akan adanya utang pajak.

6. Penanggung pajak mengajukan keberatan atas jumlah tunggakan pajaknya.

7. Kondisi keuangan penanggung pajak tidak memungkinkan jika dibayarkan sekaligus. 


\section{Efektivitas Penerimaan Pajak dengan Surat Paksa}

Efektivitas adalah pencapaian tujuan secara tepat atau memilih tujuan tujuan yang tepat dari serangkain alternatif atau pilihan cara untuk menentukan pilihan dari beberapa pilihan lainnya. Efektivitas bisa juga diartikan sebagai pengukuran keberhasilan dalam pencapaian tujuan-tujuan yang telah ditentukan. Sedangkan untuk mengukur tingkat keefektifan pajak, hal terpenting bahwa efektivitas tidak menyatakan tentang berapa besar biaya yang telah dikeluarkan untuk mencapai tujuan tersebut, efektivitas hanya melihat suatu program atau kegiatan telah mencapai tujuan yang telah ditetapkan. Pengukuran efektivitas dengan menggunakan surat paksa maka rumus yang digunakan adalah sebagai berikut:

\begin{tabular}{|cc|}
\hline Efektifitas Surat Paksa $=$ & $\begin{array}{c}\text { Jumlah rupiah yang dibayar melalui } \\
\text { surat paksa }\end{array}$ \\
\cline { 2 - 2 } & $\begin{array}{c}\text { Jumlah rupiah yang diterbitkan } \\
\text { melalui surat paksa }\end{array}$ \\
\hline
\end{tabular}

Tabel 7

Tingkat Efektivitas Penagihan Pajak terhadap Penerimaan Pajak dengan Surat Paksa

\begin{tabular}{|c|c|c|c|}
\hline Tahun & SP Terbit (Rp) & SP Bayar (Rp) & Tingkat Efektivitas (\%) \\
\hline 2011 & 8.273 .709 .039 & 3.251 .099 .607 & 2,5448 \\
\hline 2012 & 19.286 .401 .363 & 11.752 .880 .392 & 1,6409 \\
\hline
\end{tabular}

Sumber: Seksi Penagihan KPP Pratama Sleman, data diolah (2013)

Tabel 7 menunjukkan bahwa penerbitan surat paksa pada tahun 2011 di KPP Sleman tercatat Rp8.273.709.039 dan yang dibayarkan sebesar Rp3.251.099.607 atau sekitar 2,5448\%. Berdasarkan pengukuran efektivitas penerbitan surat paksa tahun 2011 tergolong tidak efektif karena tingkat efektivitas tidak mencapai $100 \%$.

Tahun 2012 mengalami peningkatan penerbitan Surat paksa sebesar Rp19.286.401.363 dan yang dibayarkan Rp11.752.880.392 atau sekitar 1,6409\%. Berdasarkan pengukuran efektivitas penerbitan surat teguran tahun 2012 tergolong tidak efektif karena tingkat efektivitas tidak mencapai $100 \%$. 
Ada beberapa hal yang menyebabkan tidak seluruh Surat Teguran tidak dilunasi oleh penanggung pajak yaitu:

1. Alamat Penanggung Pajak yang telah pindah.

2. Penanggung pajak lalai melunasi utang pajak.

3. Penanggung pajak tidak mampu dalam melunasi utang pajak.

4. Penanggung pajak tidak mengakui akan adanya utang pajak.

5. Penanggung pajak mengajukan keberatan atas jumlah tunggakan pajaknya.

6. Kondisi keuangan penanggung pajak tidak memungkinkan jika dibayarkan sekaligus.

7. Penanggung pajak meninggal.

\section{SIMPULAN, KETERBATASAN, DAN SARAN}

Berdasarkan analisis data yang dilakukan dapat diambil simpulan sebagai berikut:

1. Perhitungan efektivitas pajak dengan surat teguran di KPP Sleman menunjukkan tidak efektif yaitu tingkat penerimaan pajak yang hanya mencapai 10,2516\% di tahun 2011, sedangkan di tahun 2012 menunjukkan ketidak efektifan yaitu tingkat penerimaan pajak yang hanya mencapai $12,5451 \%$.

2. Perhitungan efektivitas pajak dengan surat paksa di KPP Pratama Sleman menunjukkan tidak efektif yaitu tingkat penerimaan pajak yang hanya mencapai 2,5448\% ditahun 2011, sedangkan di tahun 2012 menunjukkan tidak efektif yaitu tingkat penerimaan pajak yang hanya mencapai 1,6409\%.

Penelitian ini memiliki beberapa keterbatasan yaitu pada penerbitan dan penerimaan surat teguran di bulan Maret dan November tahun 2011 tidak terdapat penerimaan karena wajib pajak badan mengalami kebangkrutan, dan pada tahun 2012 di bulan Maret tidak terdapat penerbitan dan penerimaan karena juru sita mendapat tugas sebagai petugas penerima SPT tahunan. Sedangkan untuk penerbitan dan penerimaan surat paksa tahun 2011 pada bulan Maret tidak terdapat penerbitan dan penerimaan dikarenakan juru sita mendapat tugas sebagai petugas 
penerima SPT tahunan dan di tahun 2012 pada bulan Juni tidak terdapat penerimaan karena wajib pajak bangkrut dan ada indikasi tidak membayar pajak.

Berdasar simpulan da keterbatasan yang telah diuraikan, sebagai masukan bagi instasi yang berwenang dalam upaya peningkatan penerimaan pajak, maka dapat disarankan sebagai berikut:

1. Sebagai instasi yang berwenang dalam penagihan pajak di wilayah kerja Kabupaten Sleman hendaknya melakukan sosialisasi perpajakan ke berbagai sekolah, dan pendekatan dengan masyarakat, karena kurangnya pemahaman masyarakat tentang betapa pentingnya membayar pajak.

2. Membuat spanduk untuk meningkatkan kesadaran masyarakat dan memberikan informasi tentang pelaporan dan pembayaran pajak.

3. Membuat leaflet atau selebaran agar masyarakat lebih jelas dan tahu bagaimana tata cara perpajakan yang sebenarnya dan manfaat apa yang diterima.

4. Membuat pengumuman di media cetak maupun elektronik, bisa juga dengan melakukan siaran radio tentang perpajakan.

5. Melakukan penelitian dan pemeriksaan atas surat teguran maupun surat paksa yang diterima.

\section{DAFTAR PUSTAKA}

Brotodihardjo, R Santoso. 2008. Pengantar Ilmu Hukum Pajak. Bandung: Refika Aditama.

Erwis, Adriana Nana. 2011. Efektivitas Penagihan Pajak dengan Surat Tguran dan Surat Paksa terhadap Penerimaan Pajak pada Kantor Pelayanan Pajak Pratama Makasar Selatan. Skripsi. Makassar: Universitas Hasanudin (online). http://www.Google.com.

Fidel, 2010. Cara Mudah dan Praktis Memahami Masalah-Masalah Perpajakan, Muarai Kencana, Jakarta.

Fatchanie, Meutia. 2007. Analisis Efisien dan Efektivitas Hasil Pemungutan Pajak Parkir di Kabupaten Sleman. Skripsi. Yogyakarta: FE-UII. 
Ilyas, Wirawan B. 2007. Hukum Pajak. Jakarta: Salemba Empat.

Ilyas, Wirawan B. 2010. Panduan Komprehensif dan Pratis Ketentuan Umum dan Tata Cara Perpajakan. Jakarta: Salemba Empat.

Ilyas, Wirawan B. 2009. Ensiklopedia Perpajakan Indonesia. Jakarta: Salemba Empat.

Mardiasmo. 2009. Perpajakan (Edisi Revisi). Yogyakarta: Andi Offset.

Purnawan, Amin. 2004. Pelaksanaan Tindak Penagihan Pajak Kaitannya dengan Kepatuhan Wajib Pajak dan Aspek Keadilannya. Jakarta: Jurnal Hukum.

Suhartono, Rudy, dan Wirawan B. Ilyas. 2011. Hukum Pajak Material. Jakarta: Salemba Humanika.

Undang-Undang Nomor 6 Tahun 1983 Sebagaimana yang telah Diubah dengan Undang-Undang Nomor 28 Tahun 2007 tentang Ketentuan Umum dan Tata Cara Perpajakan.

Undang-Undang Nomor 19 Tahun 1997 tentang Penagihan Pajak dengan Surat Paksa Sebagimana telah Diubah dengan Undang-Undang Nomor 19 Tahun 2000.

Wijoyoyanti, Mayang. 2010. Pengaruh Penagihan Pajak dengan Surat Paksa terhadap Kepatuhan Wajib Pajak di Kantor Pelayanan Pajak Pratama Jakarta Mampang Prapatan. Skripsi. Jakarta: Universitas Pembangunan Nasional "Veteran". (online). http://www.Google.com.

Didownload dari: Rizal, 2011. Sensus Pajak Nasional (Online). (http://www.hitungpajak.Wordpress.com/2011/10/07), [diakses 11/01/13].

Didownload dari: Ramadhania, 2012. Penerimaan Pajak (Online). (http://www.detikfinace.com/2012/12/23), [diakses 11/01/13]. 